Jewish emancipation, religious individualisation, and metropolitan integration: a case study on Moses Mendelssohn and Moritz Lazarus

\author{
Beginning as a representation of the cosmos, a means of bringing heaven down to earth, the \\ city became a symbol of the possible. \\ (Mumford 1961, 31)
}

Space, places and the topic of Bodenlosigkeit (homelessness, also bottomlessness) were always privileged topics in the reflections of Jewish scholars and artists unsurprisingly, given the precarious 'diasporic existence' of the Jews, bonded by shared history and a shared destiny. The cities in Western Europe which had grown, prospered and served as vessels for economic, social and cultural crystallisation since the middle of the eighteenth century held out a particular promise for immigrant Jews. They offered them hope that they would be able to escape the physically cramped conditions and the intellectual narrowness of their shtetls and emancipate themselves step by step from the strictures of religion and tradition, taking on a double identity as Jews and as Germans in the process. The path taken 'out of the Ghetto' (Katz 1973) by European Jews between 1750 and 1850 is closely interlinked with the emergence and development of the modern metropolis and with the processes of religious individualisation. The metropolis as a real and as a symbolic place creates an urban community made up of people from different social classes, professions, and geographical regions.

In the light of the fact that metropolises were grasped as symbolic proxies of Utopia from an early stage onwards, it is startling that so little attention has been paid to the relationship between religious individualisation, Jewish emancipation, and metropolitan integration since the Haskalah. To remedy this imbalance, this paper will give evidence of the integrative tendencies of the Haskalah and their interrelationship with the emergence and development of metropolitan areas.

This development will be investigated by taking up a case study on the parallel biographies as well as on the religious and linguistic writings of two German-Jewish scholars, Moses Mendelssohn (1729-1786) and Moritz Lazarus (1824-1903). The paper shows how a variety of different processes of religious individualisation are entwined with other social and political developments. The focus is in particular on forms of sociality, sociability, community and collectivity, on the questioning of traditional forms of belonging within the Reform Judaism, 
and on the question of how these factors provided social spaces for enabling the development of the personal options or paths for Jews.

The paper takes up this material for both, as a case study on the intellectual biography of these Jewish scholars, and as an approach to explore through the lens of individual cases a more general, universalistic pattern of an existing entanglement between Jewish scholarly writings, on the one hand, and processes of religious individualisation, metropolitan growth, and social as well as political emancipation, on the other. The paper will show how their writings, as well as their life stories, initiated, catalysed, and later even institutionalised these processes of individualisation, but are yet also the subsequent expression of these developments within the Jewish religion.

\section{The role of language in Judaism}

In his essay 'Meta-Rabbis,' George Steiner (b. 1929) describes Jewish scholars as commentators who stand outside the Jewish Law but continue to advance the interpretative legacy of the Jewish tradition, which he relates to Jewish thinking on language and creativity (Steiner 1976, 64-76). He credits the Jews with a certain obsession with the written word and 'a kind of Talmudic trust in the supreme dignity of text and exegesis' (Steiner 1976, 64). In this view, the traditional practice of learned study and hermeneutic interpretation ultimately led Jewish poets, philosophers, artists, and academics to revolutionise language, enrich linguistics, initiate movements founded on revolutionary theories and establish new disciplines such as sociology, which constituted itself as a distinct discipline around the turn of the last century. This subtle observation raises the question as to the extent to which Judaism or Jewish experiences were sources - perhaps hidden ones - for this theoretical work. It seems pertinent to subject the relationship between theory development and the self-image of the Jewish-German authors of these theories to further study and to examine how questions that were originally Jewish were transformed into more general, systematic theoretical questions.

The investigation of the question of how the Jewish heritage has shaped our present-day culture has largely focussed on exploring the theological context of Jewish thinking on language. The process of secularisation undergone by Hebrew from the eighteenth century onwards has been recognised and investigated, and it has been seen how the Maskilim acquired a historical perspective on the holy language of the Torah (Schatz 2009). The social and theoretical consequences of such changes in language use and in reflection on language are readily apparent: reflection on language precipitates social, historical, political, anthropological, 
aesthetic and cultural assumptions (Trabant 2006). Entering the space of a foreign culture is always bound up with linguistic or cultural barriers, and this also applied to Jewish life in the diaspora and to the migration of Eastern Jews to Western cities. The interest in the German language shown by Jews since the Haskalah has often accompanied the appropriation of new cultural or social forms. Against this background, it becomes easier to understand what Hermann Cohen (1842-1918) was driving at when he celebrated the significance of Mendelssohn's translation of the Pentateuch and the Psalms for the Jews in the following words: 'Language was to become the medicine with the power to free them from the Ghetto, and he selected the German language as the medicine for Judaism' (my own translation. The German original in Cohen 1915, 24 reads as: 'Die Sprache sollte das Heilmittel werden zu ihrer Befreiung aus dem Ghetto. Und die deutsche Sprache hat er als Heilmittel des Judentums erwählt').

Lazarus also affirmed the value of Mendelssohn's work, highlighting in particular the role of language in Jewish emancipation through education and interpreting Mendelssohn's translation as an integrative contribution to understanding between peoples:

\footnotetext{
'Again, showing profound insight, he identified and reached out for the right book, perhaps the only book that could form a bridge which would lead broad swathes of people into German intellectual territory. No other, no foreign, but their own spiritual content, the books of the Law of Moses and the Psalms were what he offered people, expressed in pure German: in their own soul they were to receive the link that connects Jews and Germans [...] For the power of language over the soul was something he recognized from an early stage' (Lazarus 1887, 181-223, here 202). (My own translation. In the German original it reads as: 'Wiederum mit wunderbar tiefem Blick und Griff wählt er das rechte, vielleicht das einzige Buch, das für breitere Schichten die Brücke bilden konnte, um sie darauf in deutsches Geistesland zu führen. Keinen anderen, keinen fremden, sondern seinen eigenen geistigen Inhalt, die Bücher des mosaischen Gesetzes und der Psalmen bietet er dem Volke in reiner deutscher Sprache; in ihrer eigenen Seele sollen sie das Band empfangen, das den Juden und den Deutschen verbindet; [...] Denn welche Macht die Sprache für die Seele hat, hat er früh erkannt und oft dargestellt').
}

There are various reasons for the keen interest of Jewish-German scholars in language, and for the diverse variety of language concepts that originated within this group. The language of the sacred scriptures in religious contexts and the language of Yiddish in day-to-day communication were and are what links Jews around the world. Heinrich Heine put his finger on the symbolic significance of scripture for the Jewish diaspora when he called the Torah a 'portable fatherland.' The formative experiences of living in the diaspora, in outer and inner exile, often walking a tightrope between inclusion and exclusion over real and metaphysical bottomless chasms, was bound to raise questions about the cultural and 
social significance of language, about multilingualism and about human sociality through language, especially in combination with the experience of living in multilingual and multicultural contexts.

Many Jewish-German scholars, writers, and artists came up with theories about language or reflected on the conditions, possibilities, and limits of language and language loss in their writings on religious, philosophical, political, anthropological and aesthetic themes. These scholars had often been raised multilingual. They cultivated the traditional Jewish relationship to textual scholarship and often possessed an acute sensitivity to the expressive powers of language - something which was also reflected in a tendency to take up genres such as the philosophical essay, in a predilection to speak in riddles and metaphors, in the ready wit of much Jewish humour, and in a high output of literature and poetry. In this latter context, one only needs to think of the many Jewish-German poets from Czernowitz, Prague and Vienna - among them such prominent names as Theodor Lupul (1838-1858), Rudolf Kommer (1887-1943), Rose Ausländer (1901-1988), Itzig Manger (1901-1969), Paul Celan (1920-1970) and Selma Meerbaum-Eisinger (1924-1942).

Language as identity and the loss of this identity as the loss of a homeland was a topic tackled by Jewish scholars on numerous occasions. Not only were many Jews socialised in multilingual environments; scripture and its interpretation played a prominent role in the education of Jewish children, who received instruction in Talmud studies from their fathers or from local rabbis well into the nineteenth century. It is also worth recalling the particular position occupied by Germany in eighteenth and nineteenth century Europe: Other nation states had long since emerged, but Germany was still fragmented into separate territories and existed only as what intellectuals such as Johann Gottfried Herder (17441803) and Wilhelm von Humboldt (1767-1835) defined as a Kulturnation. As such, Germany appeared to represent a positive utopia in which people of different nations and confessions could co-exist peacefully. Humboldt understood the Kulturnation as a community whose members had developed a feeling of belonging through their shared participation in art, literature, language, and customs. By this logic, belonging to the nation did not result from one's biological, national or religious origins but was the product of becoming conscious of a sense of cultural communion.

All of those contributing to the entirety of objective culture should, in this view, belong to the nation. The conceptualisation of Germany as a Kulturnation probably also contributed to the fact that many Jews living in Germany (and, after the foundation of the German Reich in 1871, holding the same legal status as other Germans) hoped that they would be accepted without reservation as belonging to the community of all Germans. Many of them held the German language and culture in high affection and cultivated both assiduously. In the nineteenth 
century, this conception of language and culture going back to Humboldt was propagated almost exclusively by Jewish-German scholars; the enthusiasm Jewish Germans showed for Humboldt may not have been entirely unrelated to the fact that the latter had attempted to legislate for the legal emancipation of the Jews (von Humboldt 1903-1936, 97-115; see also Hubmann 2001, 125-52, here 141ff.). He did so as early as in 1809, in his role as Prussian Minister of Culture - around seventy years before the so-called 'Jewish Question' was furiously debated in the Berlin Anti-Semitism Dispute of 1879 (Boehlich 1965; for a more recent account of the Berlin Anti-Semitism Dispute in English cf. Stoetzler 2008).

Apart from this interest in language originating in biographies, history, and cultural politics, reasons for the heightened sensitivity of Jewish-German scholars towards language can also be found in intellectual history and in the sociology of knowledge: language stands between nature and culture. The fact that the ability to produce language is part of human nature, but that language as it is spoken is culturally determined and continually evolving, may go some way towards explaining why language theories formed such contested territory in the periodic skirmishes which broke out between the natural sciences and the humanities from the late eighteenth century onwards and escalated further in the nineteenth century. Heymann Steinthal (1824-1899), for example, expressed scepticism in his annotated edition of the linguistic works of Wilhelm von Humboldt about nativist language theories emanating from circles surrounding the noted Indogermanist August Schleicher (1821-1861) (Schleicher 1863; cf. also Sander 2017, 105-145, Hartung 2003 and Lang 1989). Nor should the social and political dimensions of language be forgotten: language is a medium of communication and interaction and therefore a medium of sociality; it touches on questions of human culture and the constitution of social orders. From that point of view, it makes sense to examine the opportunities presented by human language and the workings of language when processes involving the formation of communities, inclusion or exclusion are to be described. But Jewish scholars were not only particularly drawn to language-related questions; they were also more attuned than most other scholars to questions involving places or placelessness or bottomlessness.

\section{Location and dislocation in Jewish thought}

People who live in one place lastingly and unquestionably have no particular reason to concern themselves intensively with this place - it is characteristic for Heimat (homeland or native place) that it grants identity in a manner which demands no explanations and need not be questioned. But those with no fixed 
place of residence have every reason to seek to understand and come to terms with their current location. Given the Jews' experiences of loss, exile, and life in the diaspora, it is unsurprising that the themes of place, placelessness and bottomlessness play a prominent role in Jewish thinking: a vast body of literary, cultural and religious evidence bears testament to experiences of rootlessness, mobility, migration, homelessness, and otherness (Schlör 1995). The experience of the fragility of an existence linked to one place is not singularly a Jewish one, of course, but rather an eminently modern one, linked closely to the emergence of large cities. However, this experience was often particularly dramatic in Jewish biographies, not least because many Jews underwent this experience multiple times. Even when they did not, it still formed an integral element in Jewish cultural memory and Jewish identity, as it had since the exile of the Jews to Babylon. It was also often the case that even successful Jewish immigrants found their legal and social status in their new elective homes to be precarious.

The exceptional level of symbolic significance accorded to places is reflected in Jewish vocabulary. The Yiddish concept doikeyt can be translated as 'being here' 'presence' or 'belonging' and 'covers an entire network of experiences, attitudes, habits, and traditions which are connected to a particular place and to the relations among the Jews living in that place' (Schlör 1995, 359). The Hebrew word makom has a similarly diverse range of meanings: it can refer to topographical and to imaginary places, as well as to a spiritual home. Attempts to understand Jewish emancipation and Jewish integration following the Haskalah can only profit from taking a closer look at the significance Jewish scholars ascribed to the metropolis. The path 'out of the ghetto' was also the route from the village communities of the shtetl to big cities. Most Jewish scholars took this historical and symbolic path, as Mendelssohn and Lazarus did, or reflected on it and were thus able to perpetuate an aspect of Jewish memory culture which was transformed into more general questions and still occupies theorists in cultural studies and sociology today.

\section{Representatives of emancipation through education}

Although Lazarus was born around a hundred years after Mendelssohn, the parallels in their biographies are remarkable: both grew up in devout Jewish families and were instructed in the Talmud as children; both were intellectually precocious, exceptionally interested in education and thirsty for knowledge, which one acquired largely auto-didactically and the other at Berlin University. Both were drawn from a rural or small-town setting to the metropolis Berlin, both rapidly established 
themselves in learned intellectual circles, both worked towards the renewal of Jewish traditions, and both profited from Berlin's urban environment, although their legal and social status there was precarious at times. Finally, both were publicly challenged over their Jewish faith: Mendelssohn in 1770 in a controversy with Johann Caspar Lavater (1741-1801) and Lazarus around a hundred years later (1879) in the Berlin Anti-Semitism Dispute, by his antipode Heinrich von Treitschke (1834-1896).

Moses Mendelssohn, born in Dessau in 1729, was instructed in the Talmud from his childhood onwards, first by his father, and later in the local Talmudic school, as well as by the chief rabbi in the Duchy of Anhalt, David Hirschel Fränkel (1707-1767). He reached the city of Berlin when he was thirteen years old, as a protected Jew and in the charge of his beloved teacher Fränkel (Knobloch 1987). Legend has it that the young Moses, still called Moses Dessau at this point, walked for five days to reach the Prussian capital. At the time, Jews needed to gain permission to enter the city of Berlin. When Mendelssohn, standing before the city walls, was asked what he wanted to do in Berlin, his terse answer was: to learn. Whatever the legend, the young Moses took his studies seriously, acquiring second-hand copies of the books of John Locke (1632-1704) and Shaftesbury (1671-1703) and teaching himself English, French and Latin. He earned his living as a private tutor in the house of silk merchant Isaak Bernhard. The importance of such tutoring for the Haskalah should not be underestimated; many Maskilim worked as private tutors in the households of wealthy Jewish families and consequently had a direct influence on the socialisation and education of their pupils. In this way, they were able to gradually implant reformist ideas in the minds of coming generations, so that no major upheaval took place, but rather an inner fermentation and reinterpretation of religious ideas and inherited traditions.

The role of the metropolis as an intellectual and cultural centre also enabled Mendelssohn to become active as a literary critic, contributing both to the periodical 'Briefe, die neueste deutsche Literatur betreffend', which was edited by Friedrich Nicolai (1733-1811) and Gotthold Ephraim Lessing (1729-1781), and to the 'Teutsche Merkur' produced by Christoph Martin Wieland (1733-1813). Mendelssohn finally became well-known beyond the borders of the city in the 'Lavater controversy.' The Swiss philosopher and pastor Johann Caspar Lavater, mainly known today for founding the study of physiognomy, had sent Mendelssohn a copy of his translation of Charles Bonnet's (1720-1793) 'Inquiry into the Evidence for Christianity.' He publicly challenged Mendelssohn to disprove the theses of the noted theologian or to convert to Christianity (Lavater 1770).

It cannot have been easy for the modest and mild-mannered Mendelssohn to take up this challenge, but he reacted with equanimity and replied that Bonnet's proofs could be used to defend any religion, but that he was, and would remain Jewish, out of a sense of deep conviction (Knobloch 1987, 167). In his 1770 letter to 
Karl Wilhelm Ferdinand, Duke of Brunswick-Wolfenbüttel (1735-1806), Mendelssohn finally wrote, in the spirit of the Enlightenment postulate of tolerance: 'As all people are destined by their creator for eternal bliss, a religion which excludes those who do not adhere to it from this cannot be a true one' (Mendelssohn 1968, 556: 'Da die Menschen alle von ihrem Schöpfer zur ewigen Glückseligkeit bestimmt sind, so kann eine ausschließende Religion nicht die wahre sein.' For an English account of the debate between Mendelssohn and Lavater, see Meyer 1967, 29-56). He addressed Bonnet with the lines: 'What a happy world we would live in if all men accepted and practiced the truths that the best Christians and the best Jews have in common' (Mendelssohn 1968, 532. English translation from Meyer 1967, 33: 'In welcher glückseligen Welt würden wir leben, wenn alle Menschen die Wahrheiten annähmen und ausübten, die die besten Christen und die besten Juden gemeinsam haben').

The figure of Nathan in Gotthold Ephraim Lessing's drama Nathan the Wise, which was published in 1779, had its premiere four years later in Berlin, and it contained an implicit plea for inter-religious dialogue, was based on Mendelssohn. The debate rumbled on for several years and was followed widely, with Johann Gottfried Herder (1744-1803), Immanuel Kant (1724-1804) and other noted theologians and philosophers criticizing Lavater's provocation. Even Charles Bonnet himself, the author whose work had given rise to the controversy in the first place, excused himself publicly for Lavater's affront. Lavater persisted in his attempts to fish for Jewish souls despite his lack of success in the case of Mendelssohn, and eventually elicited a mocking satire from Georg Christoph Lichtenberg (1742-1799), which the latter published in 1773, using the pseudonym Conrad Photorin, with the amusing title 'Timorus: or, Defence of Two Israelites Who Were Moved to Convert to the True Faith on the Strength of Lavater's Arguments and Göttingen Sausages' (Knobloch 1987, 171). In the original German Lessing's piece was entitled Timorus, das ist die Verteidigung zweier Israeliten, die durch die Kräftigkeit der Lavater'schen Beweisgründe und der Göttingischen Mettwürste bewogen, den wahren Glauben angenommen haben; for a detailed account of the controversy in English, see Real 2005, $110 \mathrm{f}$.).

After Lavater had been forced to put up with his missionary efforts being compared to the seemingly irresistible taste of smoked pork, the search of this man of God for Jews he could convert faded from public view. As in so many other cases, humour offered a tried and tested defence against provocations and hostilities - it is no coincidence that jokes have a long, rich and distinct tradition of their own in Judaism as well as in other cultures.

About a century after Mendelssohn had reached Berlin from the small world of Dessau, Lazarus followed his intellectual preceptor to Berlin from Filene (now Wieleń), a small, polyglot German-Polish town in the Prussian Province of Posen. Lazarus had grown up speaking Yiddish, and in his autobiography, he 
describes his efforts to learn to speak High German without an accent (Lazarus 1913). Much in the spirit of his role model Mendelssohn, he viewed the German language as the key that would open up the entire culture of the Wilhelmine Empire to him (cf. also Sander 2017, 145-182 and Sander 2009). Lazarus lived in the Second German Empire, in which Jews had been granted full legal rights but were continually confronted with anti-Semitic challenges that culminated in the Anti-Semitism Dispute. Like most other Jewish-German academics, he was never appointed to a full professorship in Germany. He was appointed to a professorship in Berne, Switzerland in 1860, and remained in that position for six years, before he found himself drawn back to Berlin, where he ran a literary salon together with his first wife, Sarah Lazarus née Lebenheim (1819-1894), and after her death with his second wife, the writer and actor Nahida Ruth Lazarus née Sturmhöfel (1849-1928), who had converted to Judaism.

The salon was vividly frequented by academics, politicians, writers, and artists, among them popular personalities such as Georg Simmel (1858-1918), Theodor Fontane (1819-1898), Wilhelm Dilthey (1833-1911), Berthold Auerbach (1812-1882) or the painter Adolf Menzel (1815-1905). In the spirit of the Enlightenment ideals of eighteenth century salon culture, Lazarus was an enthusiastic proponent of the idea of emancipation through self-improvement and sociability. In the era of Enlightenment, and subsequently in the German Empire, the opportunities for upward mobility and advancement through education offered by salons were taken advantage of by Jews, but also by women: it is probably no coincidence that the best-known women of the eighteenth and nineteenth century were frequently the hosts of such salons. Some of the most famous salonnières included Mendelssohn's daughter Dorothea Schlegel (1764-1839), Henriette Herz (17641847), Arthur Schopenhauer's mother Johanna Schopenhauer (1766-1838), Rahel Varnhagen (1771-1883), Bettina von Arnim (1785-1859), Henriette Solmar (17941888), Fanny Lewald (1811-1889), Clara Mundt-Mühlbach (1814-1873), Hedwig Dohm (1831-1919) and Misia Sert (1872-1950), among others (Wilhelmy 1989).

\section{The language theories as matrices for understanding alterity or otherness}

The ability to read and write multiple languages belonged to the achievements and ideals of Jewish scholars from an early stage. The Jewish scribe and priest Ezra, author of the Old Testament book of the same name, acknowledged the necessity of translating sacred texts as far back as 400 BCE, when there were already Jews living in the diaspora, surrounded by foreign languages and cultures (Bechthold 
2005). The act of translation as opening up new horizons of meaning, or as a transfer from one field of meaning to another, was a central topic pursued by Jewish intellectuals from the Haskalah onwards. During the epoch of the Jewish Enlightenment, Mendelssohn initiated this trend with his Hebrew-German translations of the Pentateuch and the Psalms - a project which he worked on from the middle of the seventeen-seventies onwards in collaboration with other Maskilim, among them Salomo Dubno (1738-1813), Herz Homberg (1749-1841) and Naphtali Herz Wessely (1725-1805). Mendelssohn had initially intended his work to be used for the instruction of his children in language and religion but shortly afterward he saw the opportunities the translation offered to make the ideas of the Haskalah accessible to all German-speaking Jews. He had the translation printed as a bilingual edition, with the Hebrew text next to his German translation, which was also printed in the Hebrew alphabet. The translation was manifestly intended for Mendelssohn's Jewish contemporaries. In the tradition of rabbinical interpretation of scripture, Mendelssohn accompanied the translation with a Bi'ur or commentary and termed the entire work Sefer netivot ha-Shalom, which means 'Book of the Paths of Peace.'

Different interpretations of Mendelssohn's primary motive for carrying out the project exist. The translation is frequently seen as providing a possibility for opening up in the direction of German culture and language - often, revealingly enough, by Jewish scholars themselves. Others have asserted that Mendelssohn's main motivation was to bring Holy Writ closer to German Jews who would now be able to read Hebrew and to start the rediscovery of buried Jewish traditions (Römer 1994, 49-58). Mendelssohn's own testimony allows both interpretations but stresses the practical aspects of the project. The Bible translation was to enable a resourceful paterfamilias to educate his children in the spirit of Judaism. But this finding should not distract from the fact that Mendelssohn, like Lazarus a hundred years later, was interested in improving the situation of Jews in Germany by familiarising them with the German language and culture. This can be seen as a form of acculturation. In a letter to his friend August von Henning (17481826), Mendelssohn described the 'better translation and explanation of the Holy Books' as a 'first step to culture, something from which my nation, sadly, is kept at such remove that one might almost despair of the possibility of an improvement' (Mendelssohn 1976, 148f. The English translation is cited from Meyer 1967, 43).

When modern Jewish schools were being set up under the Habsburg monarchy as a result of the tolerance patents issued by Joseph II (1741-1790) from 1782 onwards, Mendelssohn sent the theologian tasked with reforming the school system in Bohemia, Ferdinand Kindermann Ritter von Schulstein (1740-1801), finished sections of his as-yet incomplete translation. He added by way of explanation that the translation had occupied him for a long time 
as a way of delivering a German translation into the hands of the youth of his own nation that would conform to their religious principles (Mendelssohn 1977, 97f.). In the light of Mendelssohn's insistence on the inviolate nature of the text of the Torah and his preference for literal rather than interpretative commentary, it is surprising to see how severely his text was criticised soon after its publication. Ezekiel Landau (1713-1793), chief rabbi in Prague and Bohemia from 1754 onwards, criticised Mendelssohn's project in the strongest terms, maintaining that it reduced the Torah to the role of a maidservant to the German tongue (Brenner, Lowenstein, Meyer 1996, 291). Critical voices such as these speak volumes about the level of upheaval in traditional Judaism sparked by Mendelssohn and other Maskilim. But scolding was not enough to prevent the success of the book: even the first edition of 750 copies found purchasers in such far-flung locations as Holland, Poland and Russia, and in the century between 1783 and 1888 seventeen new editions of the work appeared. With this, the innovations of the Maskilim had entered the mainstream and the liberal Reform Judaism, which Lazarus, among others, would come to represent, had been established.

As was also the case for many other Jewish-German scholars in the Wilhelmine Empire, Lazarus found himself standing between the enlightened world of Western culture on the one hand and the Jewish traditions he sought to reform on the other. Lazarus presided over the first and second Israelite Synods in Leipzig (1869) and Augsburg (1871). Extensive reforms of Jewish religious ceremonies, prescriptions on clothing and food, as well as legal matters, were discussed on both occasions. At the Leipzig synod, for example, songs and psalms in the German language and organ music were introduced into the synagogues. At the Augsburg synod, various legal reforms were passed, including the involvement of the bride and the mutual exchange of rings in marriage rites, the admittance of testimony given by women in courts, the abolition of the chaliza and the legitimisation of driving on the Sabbath for charitable or religious reasons.

Without exploring these reforms in further detail, it can be noted that the effect of this modernisation was to bring Jews closer to Western culture. Lazarus understood the synods above all as attempts to establish a balance between Jewish religiosity and the ability to lead a social existence bounded by the same legal norms that applied to others (Lazarus 1869; Philipson 1907, 307ff.; Malamat 1976, 836ff.; Brenner, Lowenstein, Meyer 1997, 116ff., 137ff.). In his late work The Ethics of Judaism, he explored the role of the stranger and love for strangers from the perspective of Jewish religiosity. He cited the Talmud and Talmud commentaries as sources for Jewish moral teachings and explained the high esteem accorded to strangers in Jewish religiosity in terms of the Jews' own experience of exile in Babylon (Lazarus 1898, 87. See also Sander 2017, 341-382). 
What is particularly remarkable is the fact that Lazarus saw Jewish moral teachings as a form of social ethics - for, according to him, 'true recognition of man's destiny in this world can be reached only on the basis of a social philosophy' (the English citation is taken from Lazarus 1900, 187; in the German original in Lazarus 1898, 142 it reads as: '[...] in der Sittlichkeit aber spielt gerade die Gesammtheit die Hauptrolle; alle Ethik ist (wie schon angedeutet wurde und weiterhin noch genauer dargelegt werden soll) wenn nicht ganz und gar, dann doch vorzugsweise S o c i a l e t hi k. - Das Dogma des Jenseits gründet sich lediglich auf eine Philosophie des Ich; alle wahre Erkenntnis aber von der Bestimmung des Menschen, zunächst im Diesseits, wird nur auf dem Grund einer Philosophie des W ir gewonnen werden').

The task of the new discipline he initiated, Völkerpsychologie or ethnopsychology, ${ }^{1}$ was to be the examination of the cultural and social dynamics, which arise as a result of people interacting with each other. Lazarus stressed that social ethics was not a national principle but a universal one: 'We shall see how, from the unity of mankind, the equality of all nations was deduced, and furthermore, within the ranks of each nation, the equality of all its members. One law for all - no hereditary privileges for the one or the other estate or family' (the English translation is taken from Lazarus 1900, 195; in the German original in Lazarus 1898, 148f. it reads as: 'Wir werden sehen, wie aus der Einheit die Gleichheit aller Nationen abgeleitet ist, aber auch innerhalb der Nation die Gleichheit aller Glieder; einerlei Recht und einerlei Gesetz für Alle, also daß alle erblichen Vorzüge einzelner Stände und Geschlechter verschwinden').

Lazarus rejected evolutionist schemes of history and with them biological or racial definitions of human dignity, stressing that the Talmud contained multiple allusions to the necessity of according respect to strangers. In a lecture he gave to the general assembly of the Hochschule für die Wissenschaft des Judentums (Higher Institute of Jewish Studies) in 1879 he took a stand against the nation-state theories recently expounded by Heinrich von Treitschke (1834-1896) at Berlin's university, and against Treitschke's anti-Semitic rhetoric. In his lecture, Lazarus argued that

1 Völkerpsychologie is not a concept easily rendered in English. Urs Fuhrer considers 'folk psychology' to be merely an 'absurd mistranslation' and observes that 'cultural psychology' and 'Ethnopsychology' are both closer but still open to various objections. See Fuhrer 2004, 41. Ivan Kalmar notes that Lazarus and Steinthal called their new discipline a branch of psychology, shying away from terms such as ethnology and anthropology because both terms were strongly focused on issues of biology and race at the time. The irony that the two scholars, who more than anyone foresaw the direction that anthropology was to take, were forced to reject anthropology as a term is not lost on Kalmar, who points out that both scholars would surely be better known among anthropologists today if they had opted to use the word. See Kalmar 1987, 671-90, here 673. For a more detailed account on the concept of Völkerpsychologie, see Sander 2017, 145-82. 
communities were not constituted by such objective traits as race, origin, blood relationships, religion or character (Lazarus 1880; an English translation of Lazarus's lecture is available in Stoetzler 2008, 317-59). He made no reference to external determinisms in explaining the emergence of history, opting rather to accentuate the impact of the imagination, emotions, subjective will and sense of selfhood of the actors involved as necessary and adequate factors for the development of a community: 'That which makes a nation a nation lies [...] in the subjective views of the members of the nation, all of whom regard themselves as its members. The concept of a nation rests on the subjective view of the members of the nation of themselves' (my own translation from the original German, from Lazarus 2003, 88; in the original it reads as: 'Das, was ein Volk zu eben diesem macht, liegt [...] in der subjektiven Ansicht der Glieder des Volkes, welche sich alle als ein Volk ansehen. Der Begriff Volk beruht auf den subjectiven Ansichten der Glieder des Volks selbst von sich selbst').

Such a description applied to the inclusion of the Jews in the German Empire - although they were not of Aryan origin, they belonged to the German nation through a common language and through education and participation in cultural and political life. Culture, as Lazarus concluded emphatically, was the product of diversity. While Lazarus opposed the biological understanding of a nation held by Heinrich von Treitschke, his views also differed from those of Theodor Mommsen (1817-1903). Mommsen was in favour of complete assimilation of the Jews but Lazarus pleaded for an alternative model of acceptance of what is foreign to ourselves. With this approach, the Jewish-German theorist had anticipated the concept of the construction of nations and identities, a model which asserts that belonging to a community is a process negotiated through active involvement in the life of that community.

Seen from this point of view, nations do not appear as pre-existing entities or realities but as specific historic and cultural projections. In this context, it is noteworthy that Lazarus' lecture manuscript 'What does national mean?' was passed on to Ernest Renan (1823-1892), who made reference to it in correspondence and seems to have incorporated much of Lazarus' thinking into his seminal essay ' $Q u$ ' est-ce qu'une nation?.' While no mention of Lazarus is made in Renan's essay, Lazarus was justified in assuming that his work had influenced Renan (Smith 2008, 111-3 as well as Jansen and Borggräfe 2007, 138). As such projected or 'imagined' communities are not bound by territorial borders, they can function as the connection which links people in a diaspora, in as much as members feel a sense of belonging towards the imagined community, wherever in the world they may find themselves (Anderson 1983).

In Völkerpsychologie, or the ethno-psychology developed by Lazarus, language has a double function. Both aspects are reflected in the concepts of 'condensing of thinking' and 'appropriation' which lie at the core of his theory 
of the 'objective spirit': language is an expression of the spirit of the whole group because it stores knowledge which has crystallised during centuries of human history. It is also the medium through which such knowledge is acquired: language makes it possible for individuals to participate in shared, collective beliefs and ideas, in the objective spirit of a community. Lazarus accorded particular significance to Volksschriften, or folk literature, extolling the significance of Homer for the Greeks and the importance of fairy-tales or the Bible for his own era. In these texts, collective interpretations of the world, shared values, desires, hopes, and fears, in short, the sum total of human imagination is condensed. Folk literature has a relevance which transcends epochs and social class: 'Good folk literature evens out intellectual injustices, and the Bible is a spiritual sun which casts its rays into huts and palaces alike and warms and illuminates both' (my own translation from the original German in Lazarus 2003, 72; in the original it reads as: 'Gute Volksschriften ebnen die geistigen Ungleichheiten aus, und die Bibel ist eine geistige Sonne, welche in die Hütte wie in den Palast ihre Strahlen wirft und hier wie dort erleuchtet und erwärmt'). The study of various languages and their canonical texts gives information on the imaginative capacity of society and on the ideas about the world shared by the collective. From that point of view, language - both academic research on language and the practical acquisition and use of language - is the key to culture. Through language, the close links which bind individuals to their respective communities are established.

Apart from his general interest in linguistics, Lazarus also devoted attention to the everyday conversation long before an interest in the workings and effects of everyday conversations became a fashionable topic in linguistics and communication studies circles (Lazarus 1986). Dialogue with others, even 'small talk,' preserves what we are familiar with and ensures orientation on values, norms, and experiences. Over and above these factors, language allows us to appropriate new thoughts, to share the experiences and thoughts of others, and to understand their views of the world. Lazarus argued that dialogue is the basis for building communities but also saw that interactions through the medium of language paved the way for a cultural and social change. For the act of speech - as Humboldt had already acknowledged when he categorised language as energeia rather than as ergon - changes as it is executed; it is a continual process which in turn impacts on culture and creates invisible bonds between people: 'But conversations do not simply reinforce themselves; they have a purifying and uplifting effect on public opinion. They transform many smaller and larger minds into one great, public spirit' (my own translation from the original German in Lazarus 1986, 41; in the original German it reads as: 'Aber die Gespräche befestigen nicht bloß, sie läutern und heben die öffentliche Meinung; sie machen aus den vielen kleinen und mittelmäßigen Geistern einen großen, öffentlichen Geist'). 
A shared language and everyday conversations create an inter-subjective reality, an objective culture within which the individual manoeuvres. At the same time, speech is the privileged medium for the appropriation of the material objectification of cultural forms, such as architecture, art, technology or utilitarian objects, but also for appropriating its immaterial manifestations, from tact and morals to customs and habits. When children learn their native language, they acquire - in the process - the sum total of their own objective culture. Seen from this point of view, according to Lazarus, linguistic research offers insights into the imagination and attitudes of collectives. At the same time, language is the intellectual tool which assists in understanding what is foreign to us and integrating it into our own experiences.

The perceptions of language and culture of Jewish-German scholars allow us highly revealing insights into the historical and political changes that took place in the two hundred years between the Jewish Enlightenment and the eve of National Socialism and in the different environments of the Prussian state, the German Empire, and the Weimar Republic. Mendelssohn had understood his translation as the first step towards that culture which his nation had previously been so far removed from as to despair of the possibility of improvement - and thus begun a process of crossing over from German Jewishness to Jewish Germanness, setting an important precedent in the process. It is revealing that the practice of translating scripture by Jewish-German scholars reached its zenith in the Second Empire, when pressure to assimilate was running at a particularly high level. From the middle of the nineteenth century right up to the Second World War, not a single decade passed without at least one Jewish Bible translation being published in German (Bechthold 2005). For the children and grandchildren of the Maskilim and the Reformed Jews, however, the Hebrew language and Jewish religiosity often appeared to be merely empty shells. Among other sources, Franz Kafka's 'Letter to his father' - a letter which was never sent - bears witness to this. Kafka maintains that his father's Judaism was devoid of real faith, 'a mere nothing, a joke'. He rejects his father as a role model with an accusatory flourish: 'Had your Judaism been stronger, your example would have been more compelling too' and he describes how the residue of Jewish culture his parents still possessed was lost: 'Even in this there was still Judaism enough, but it was too little to be handed on to the child; it all dribbled away while you were passing it on' (Kafka 1975; English translation cited from Kafka 1966).

The environment described here - awareness of the loss of Jewish traditions and attempts to return to the roots of Jewish religiosity and culture - finally formed the historical background to what has been the last major Jewish-German Bible translation to date: right on the eve of the rise of Nazism to power, Martin Buber (1878-1965) and Franz Rosenzweig (1886-1929) began their Verdeutschung 
der Schrift, a 'Germanification' of the Hebrew Bible (Buber, Rosenzweig 19561968). Their translation stood exactly on the margin between two languages and cultures, in that the Hebrew text was translated into German but the cadences of the original Hebrew were retained, so that a new and unusual language emerged. Buber and Rosenzweig aimed to create a new work which would run against the grain of readers' expectations and in this way bear testament to the irreducibility of the experience of the ineffable. In their synthesis of Old Hebrew and German, Jewish faith in revelation and a creative reworking of the German language were to be moulded into something new, a third element that would extend the range of what could be thought and perceived, a language and culture in which German and Jewish elements would condense to form a new whole (Rosenzweig 1926). Buber and Rosenzweig created a Hebraic German to give their contemporaries, most of whom were rooted fast in the German language and had no knowledge of Hebrew, a sense of the holy language of their ancestors. With that, they strove to initiate a 'Renaissance' of lost Jewish traditions as an answer to the acculturation of German Jews which had gone before and only shortly prior to the unleashing of National Socialism's horrific and vast destructive potential.

\section{The metropolis as the pre-condition for emancipation and individualisation}

Against the background of prototypical Jewish metropolitan biographies, such as those of Mendelssohn and Lazarus, and the resultant body of theoretical work, numerous scholars from diverse academic disciplines, many of them Jewish, have devoted considerable attention to studying the consequences of these metropolitan developments. They have focussed on the spatial and social order of the metropolis, its population structure and the cultural, social, psychological and imaginary dispositions and mentalities which developed through the coexistence of diverse social classes, nationalities, and cultures. In order to get to the heart of the distinct qualities of life in the metropolis, representatives of the emerging discipline of social theory postulated the existence of typical figures, such as the 'marginal man' and the 'stranger.'

Reflections of this nature can aid us in gaining a perspective on the huge revolutionary significance of the lives of Mendelssohn and Lazarus. Robert E. Park's social type of the 'marginal man' fits both Jewish-German scholars perfectly (Park 1928, 881-93). Park conceived of the 'marginal man' as existing in an urban setting on the fringes of more than one world, occupying a marginal, borderline position. But Park's main point is not that the 'marginal man' is separated 
from the homogeneous mainstream community by a border. Rather, it is that the 'marginal man' finds himself on this border between several antagonistic cultures. The 'marginal man' is a product of migration and acculturation; Park saw assimilated and emancipated European Jews as prototypical representatives of the concept. What is described in spatial metaphors as a borderline existence results in subjective feelings of ambivalence. Both models, adaptation to a new cultural system of reference and self-assertion within a group one does not quite belong to, require a homogeneous frame of reference which must be negotiated and created through forms of exclusion, distancing oneself, and attributive processes. As a result of this intermediate position, the 'marginal man' advances social change and cultural developments: finding otherness within himself and something of himself in others, he joins both to form a third entity. Mendelssohn and Lazarus straddled the margin between Jewish traditions and Western Enlightenment humanism and can thus be considered representative cases for this model.

Park's concept of the 'marginal man' also bears witness to the fact that he spent a semester studying in Berlin under Georg Simmel, who was both one of the founders of sociology in Germany and a student of Moritz Lazarus. Simmel's highly detailed observations and descriptions of the dynamics of the development of the metropolis and its cultural and social forms were ground-breaking when first published early in the twentieth century, and they are still highly relevant today (Simmel 1900; Simmel 1903, 185-206). Simmel observed that the metropolis is an environment that allows the individual a great degree of anonymity but also promotes the 'intersection of social circles' in a manner which he saw as a prerequisite for the emergence of individuality. Individuality arises, according to Simmel, when people belong to various social circles or groups at the same time and is found in the unique area of intersection between these different circles (Simmel 1908, 305-44). Above and beyond his seminal work on the metropolis, Simmel was also preoccupied with the figure of the stranger as a person 'who comes today and stays tomorrow' (Simmel 1908, 508-12, here 509). Strangers are characterised primarily by the interaction of proximity to and distance from a given community - they are not 'inhabitants of Sirius' (Simmel 1908, 509), so far away as to be imperceptible, but those who find themselves amid a homogeneous group from which they are separated not in spatial terms but through a cultural or social border. Simmel maintained that this ambivalent position between proximity to and distance from a (closed) group gave strangers the ability to regard existing structures and social orders objectively and to anticipate change particularly sensitively. Simmel himself, and before him Mendelssohn and Lazarus, were certainly all particularly well-attuned to the sociocultural environment around them. 
It should be clear from the overview given of the biographical stations and theoretical concepts of Mendelssohn and Lazarus that metropolitan Berlin had enormous significance for the Jewish emancipation movement and for Reform Judaism. The Enlightenment in Europe and its tender offshoot, the Haskalah, began in big cities because these places, with their schools, universities, publishing houses, printers, associations, literary salons, and coffee-houses, provided the locations and the points of intersection where education, the exchange of ideas and networks could be initiated and deepened. Drawing on Simmel, Louis Wirth (1897-1952) came to define urbanity as a specific way of life, a 'complex of traits which makes up the characteristic mode of life in cities' (Wirth 1938, 8). In Wirth's views, the typical features of this urban way of life are segmented role relationships, memberships to different groups, the loss of family ties, and forms of contact with others which are anonymous but tolerant of social and cultural differences. A highly concentrated population creates the critical mass required for specialist demands to emerge and so makes the formation of cohesive networks and subcultural institutions and movements easier (Fischer 1995, 543-77).

Cities were always places where different lifestyles and subcultures intersected and interacted. Competition between multiple parallel strands of thinking makes social dynamism, innovation, and progress possible. The pulsating atmosphere and vibrant social life in eighteenth and nineteenth century Berlin, with its coffee houses, salons and learned circles, created the fruitful ground for Jewish-German emancipation. This occurred not least because cities such as Berlin had a large number of journals, publishers, and printers; this allowed for the quick dissemination of new experiences and different cultures of knowledge that could enter into cultural memory. Encapsulated in books and other publications, this knowledge and this culture took on a portable quality, which ultimately meant that the Jews who emigrated were able to take it with them.

\section{Conclusion and prospects}

This paper draws on early social theory texts and biographical sketches to review the impact of the metropolis on intellectual life and the impact of the 'marginal man' on the emergence of an integrative metropolitan culture. To this end, the effects of Jewish migration on the 'grammar' of urban co-existence and the role of urban structures as a catalyst for Jewish emancipation have been explored. Berlin provided opportune conditions for the Haskalah movement, resulting from its rapid population expansion and its increasingly important position as the capital of the Prussian kingdom; but also the fact that the metropolis, as a location of 
cultural and social crystallisation, always accommodated alterity as well as homogeneity, goes a long way in explaining the fruitful role of the big cities for the movement of the Haskalah and for processes of religious individualisation.

The biographic paths of Mendelssohn and Lazarus are paradigmatic for a process of emancipation through education which was largely successful, although it must be emphasised that the striking degree of optimism in the ideas voiced by Mendelssohn, Lazarus, and other Jewish-German intellectuals (see Sander 2017) was at stark variance with the actual political realities of their respective eras: both Mendelssohn and Lazarus were confronted with modern anti-Semitism in various forms. Their conceptions of language, culture, and national identity can be interpreted as intellectual 'parallel worlds' which they set against the ambivalent social and political realities they encountered in respectively - the eighteenth and nineteenth centuries.

The study of intellectual biographies is an excellent medium within which to identify and to better understand the manifold overlaps of personhood, individualisation, and institutionalisation, for there is no 'lonely genius' outside of society and it's agencies of socialisation and education, on the one hand, but there would be no scientific or historical progress, on the other, if it was not for those outstanding individuals who moved beyond their cultural and religious ties' or who transformed their social 'package' into a universalistic viewpoint. The investigation of intellectual biographies gives evidence of the intertwined relationship between tradition and deviance, norm and creativity, or structure and agency. Intellectual biographies also testify to the fact that there is an undeniable link between the historical experiences of a generation and its actions or cultural works. The history of ideas matters, for it is 'social imaginaries' (Taylor 2003), worldviews, ideas, and particularities that drive the history of mankind and foster social change and cultural dynamics, such as processes of religious individualisation.

This case study of the intellectual biographies of two German-Jewish scholars who were representatives of the Haskalah and the Reform Judaism testifies to multiple processes of religious individualisation:

1) Both scholars walked a tightrope between traditional bondage and deviant behaviour, and this tightrope translated in their meandering between norm and creativity, or between collectivity and individual self-assertion in their lives and writings; for the Reform Judaism allowed the expansion of the scope of action for the individual (Jew) without converting the Jewish people into renegades.

2) Both scholars had a great capacity to 'translate' their (metropolitan) cosmopolitanism, as well as their multiple cultural identities and affiliations, their status' as 'marginal men' (Robert E. Park), in a particularly fruitful way into their scientific writings and the stations of their intellectual life and career. 
3) In the writings of both scholars, deep religious piety on the one hand, and modern scientific scholarship on the other, were interwoven. It allowed for the representation of a unique social, cultural, religious, and historical constellation.

4) According to the thesis expounded here, the historical process of emancipation through education left significant traces in the writings of both scholars, in both cases weaving a type of 'cultural matrix for understanding alterity' into their work on language and culture.

It would behoove today's cultural studies practitioners and sociologists to rediscover this intellectual legacy and develop it further. Finally, the survey of the complex relationship between urban development and Jewish emancipation presented here confirms the accuracy of Lewis Mumford's description of The City in History in his opus magnum of the same name, first published in 1961:

The city first took form as the home of a god: a place where eternal values were represented, and divine possibilities revealed. Though the symbols have changed the realities behind them remain. We know now, as never before, that the undisclosed potentialities of life reach far beyond the proud algebraics of contemporary science; and their promises for the further transformations of man are as enchanting as they are inexhaustible. Without the religious perspectives fostered by the city, it is doubtful if more than a small part of man's capacities for living and learning could have developed.

(Mumford 1961, 575)

\section{References}

Anderson, Benedict. 1983. Imagined Communities: Reflections on the Origin and Spread of Nationalism. London, UK / New York, NY: Verso.

Bechtold, Hans-Joachim. 2005. Jüdische deutsche Bibelübersetzungen: Vom ausgehenden 18. bis zum Beginn des 20. Jahrhunderts. Stuttgart: Kohlhammer.

Boehlich, Walter (ed.). 1965. Der Berliner Antisemitismusstreit. Frankfurt a.M.: Suhrkamp.

Brenner, Michael; Lowenstein, Steven; Meyer, Michael. A (eds.). 1996. Deutsch-jüdische Geschichte in der Neuzeit, Bd. 1: Tradition und Aufklärung 1600-1780. München: C. H. Beck.

Brenner, Michael; Lowenstein, Steven; Meyer, Michael A. (eds.). 1997. Deutsch-Jüdische Geschichte in der Neuzeit, Bd. 3: Umstrittene Emanzipation 1871-1918. München: C. H. Beck.

Buber, Martin; Rosenzweig, Franz. 1956-1968. Die Schrift. Verdeutscht von Martin Buber in Gemeinschaft mit Franz Rosenzweig in fünf Bänden. Köln/Olten: Jakob Hegner.

Cohen, Herrmann. 1915. Deutschtum und Judentum, mit grundlegenden Betrachtungen über Staat und Internationalismus. Gießen: Töpelmann. (Online: https://archive.org/details/ deutscherzukunf00cohegoog.)

Fischer, Claude S. 1995. 'A subcultural theory of urbanism: A twentieth-year assessment', American Journal of Sociology 101. 543-77. (Online: http://myweb.fsu.edu/bstults/ ccj5625/readings/fischer-ajs-1995.pdf.) 
Fuhrer, Urs. 2004. Cultivating minds: Identity as meaning-making practice. Oxford/New York, NY: Oxford University Press.

Hartung, Gerald. 2003. 'Darwin und die Philosophen: Eine Studie zur Darwin-Rezeption im 19. Jahrhundert', Dialektik. Zeitschrift für Kulturphilosophie 2.171-91.

Hubmann, Gerald. 2001. 'Sittlichkeit und Recht: Die jüdische Emanzipationsfrage bei Jakob Friedrich Fries und anderen Staatsdenkern des deutschen Idealismus'. In Antisemitismus bei Kant und anderen Denkern der Aufklärung: Prämierte Schriften des wissenschaftlichen Preisausschreibens "Antisemitische und Antijudaistische Motive bei Denkern der Aufklärung", eds. H. Gronke, T. Meyer, B. Neißer, Würzburg: Königshausen \& Neumann. 125-52.

Humboldt, Wilhelm von. 1903-1936. 'Entwurf zu einer neuen Constitution der Juden'. In Gesammelte Schriften 10, ed. Königlich-Preußische Akademie der Wissenschaften, Berlin: Behr. 97-115.

Jansen, Christian; Borggräfe, Henning (eds.). 2007. Nation - Nationalität - Nationalismus, Frankfurt a.M./New York, NY: Campus.

Kafka, Franz. 1966. Letter to his father: Bilingual edition. Transl. E. Kaiser, E. Wilkins, rev. A. S. Wensinger, New York, NY: Schocken.

Kafka, Franz. 1975. Brief an den Vater. Frankfurt a.M.: Fischer.

Kalmar, Ivan. 1987. 'The "Völkerpsychologie" of Lazarus and Steinthal and the modern concept of culture', Journal of the History of Ideas, 48 (4). 671-90.

Katz, Jacob. 1973. Out of the ghetto: The background of Jewish emancipation, 1770-1870. New York, NY: Syracuse University Press.

Knobloch, Heinz. 1987. Herr Moses in Berlin. Ein Menschenfreund in Preußen. Das Leben des Moses Mendelssohn. Berlin: Aufbau Verlag.

Lang, Martin. 1989. 'Ursprache und Sprachnation: Sprachursprungsmotive in der deutschen Sprachwissenschaft des 19. Jahrhunderts'. In Theorien vom Ursprung der Sprache 2, eds. J. Gessinger, W. von, Rahden. Berlin/New York, NY: de Gruyter. 52-84.

Lavater, Johann Caspar. 1770. Untersuchungen der Beweise für das Christentum. Translation of C. Bonnets “Idées sur l'état futur des êtres vivants, ou Palingénésie philosophique (1769)". Zürich: Auf Kosten guter Freunde. (Online: http://digitale.bibliothek.uni-halle.de/urn/ urn:nbn:de:gbv:3:1-256217.)

Lazarus, Moritz (ed.). 1869. Verhandlungen der ersten israelitischen Synode zu Leipzig vom 29. Juni bis 4. Juli 1869 (enthaltend: Protokolle, Stenographische Niederschriften etc.). Berlin: Loius Herschel's Verlagsbuchhandlung.

Lazarus, Moritz. 1880. Was heißt national? Vortrag vom 02.12.1879 vor der Generalversammlung der Hochschule für die Wissenschaft des Judentums. Berlin: Ferdinand Dümmler.

Lazarus, Moritz. 1887. 'Zwei Reden auf Moses Mendelssohn zur Gedenkfeier seines hundertjährigen Todestages'. In Treu und Frei: Gesammelte Reden über Juden und Judenthum. Leipzig: Winter. 181-223.

Lazarus, Moritz. 1898. Die Ethik des Judenthums. Frankfurt a.M.: Winter.

Lazarus, Moritz. 1900. The Ethics of Judaism. Transl. H. Szold. Philadelphia, PA: Jewish Publication Society of Philadelphia.

Lazarus, Moritz. 1913. Aus meiner Jugend. Frankfurt a.M.: J. Kauffmann.

Lazarus, Moritz. 1986. Über Gespräche. Vortrag im wissenschaftlichen Verein der Singakademie, gehalten am 24. Februar 1876, ed. K. C. Köhnke. Berlin: Henssel.

Lazarus, Moritz. 2003. 'Über das Verhältnis des Einzelnen zur Gesamtheit (1862)'. In Grundzüge der Völkerpsychologie und Kulturwissenschaft, ed. K. C. Köhnke. Hamburg: Meiner. 39-130. 
Malamat, Abraham. 1976. A history of the Jewish people, eds. H. H. Ben-Sasson. Cambridge, MA: Harvard University Press.

Mendelssohn, Moses. 1968. Schriften zur Philosophie, Ästhetik und Apologetik (1777). Hildesheim: G. Olms.

Mendelssohn, Moses. 1976. Gesammelte Schriften. Jubiläumsausgabe 12.2: Briefwechsel II.2, 1771-1780, eds. A. Altmann, I. Elbogen, F. Bamberger. Stuttgart: Frommann-Holzboog.

Mendelssohn, Moses. 1977. Gesammelte Schriften. Jubiläumsausgabe 13: Briefwechsel III, 1881-1885, ed. A. Altmann. Stuttgart: Frommann-Holzboog.

Meyer, Michael A. 1967. The origins of the modern Jew: Jewish culture and European identity in Germany 1749-1824. Detroit, MI: Wayne State University Press.

Mumford, Lewis. 1961. The City in history: Its origins, its transformations, its prospects. New York, NY: Harcourt, Brace, and World.

Park, Robert Ezra. 1928. 'The marginal man', American Journal of Sociology 33. 881-93.

Philipson, David. 1907. The reform movement in Judaism. London/New York, NY: MacMillan. (Online: https://archive.org/details/reformmovementi00philgoog.)

Real, Hermann J. 2005. The reception of Jonathan Swift in Europe. London/New York, NY: Thoemmes Continuum.

Römer, Nils. 1994. 'Sprachverhältnisse und Leseverhalten der Juden in Deutschland 1770-1830'. In Dialog zwischen den Kulturen. Erziehungshistorische und religionspädagogische Gesichtspunkte interkultureller Bildung, eds. I. Lohmann, W. Weiße. Münster/New York, NY: Waxmann. 49-58.

Rosenzweig, Franz. 1926. Die Schrift und Luther. Berlin: Lambert Schneider.

Sander, Sabine. 2009. 'Sprachdenken im Kontext von Moritz Lazarus’s Völkerpsychologie’, Naharaim. Zeitschrift für deutsch-jüdische Literatur und Kulturgeschichte / Journal of German-Jewish Literature and Cultural History 3.102-16. (Online: http://www. reference-global.com/doi/pdfplusdirect/10.1515/naha.2009.007.)

Sander, Sabine. 2017. Dialogische Verantwortung: Konzepte der Vermittlung und des Fremdverstehens im jüdisch-deutschen Kontext des 19. und 20. Jahrhunderts. Paderborn: Fink.

Schatz, Andrea. 2009. Sprache in der Zerstreuung: Die Säkularisierung des Hebräischen im 18. Jahrhundert. Göttingen: Vandenhoek \& Ruprecht.

Schleicher, August. 1863. Die Darwinistische Theorie und die Sprachwissenschaft: Offenes Sendschreiben an Herrn Dr. Ernst Haeckel, a. o. Professor der Zoologie und Director des zoologischen Museums an der Universität Jena. Weimar: Böhlau.

Schlör, Joachim (ed.). 1995. Wenn ich dein vergesse, Jerusalem: Bilder jüdischen Stadtlebens. Leipzig: Reclam.

Simmel, Georg. 1900. Die Philosophie des Geldes [The Philosophy of Money]. Leipzig: Duncker \& Humblot.

Simmel, Georg. 1903. 'Die Großstädte und das Geistesleben [The Metropolis and Mental Life]'. In Die Großstadt. Vorträge und Aufsätze zur Städteausstellung, ed. T. Petermann. Dresden: Zahn und Jaensch. 185-206.

Simmel, Georg. 1908. 'Die Kreuzung sozialer Kreise [The Intersection of Social Circles]'. In Soziologie. Untersuchungen über die Formen der Vergesellschaftung, Leipzig: Duncker \& Humblot. 305-44.

Simmel, Georg. 1908. 'Exkurs über den Fremden [The Stranger]'. In Soziologie. Untersuchungen über die Formen der Vergesellschaftung, Leipzig: Duncker \& Humblot. 509-512.

Smith, Helmut Walser. 2008. The continuities of german history: nation, religion, and race across the long nineteenth century. Cambridge/New York, NY: Cambridge University Press. 
Steiner, George. 1976. 'Some meta-rabbis'. In Next Year in Jerusalem: Jews in the twentieth century, ed. D. Villiers, London: Harrap. 64-76.

Stoetzler, Marcel. 2008. The state, the nation, and the Jews: Liberalism and the anti-Semitism dispute in Bismarck's Germany. Lincoln, NE/London: University of Nebraska Press.

Taylor, Charles. 2003. Modern social imaginaries. Durham, NC: Duke University Press.

Trabant, Jürgen. 2006. Europäisches Sprachdenken: Von Plato bis Wittgenstein.

München: C. H. Beck.

Wilhelmy, Petra. 1989. Der Berliner Salon im 19. Jahrhundert (1780-1914). Berlin/New York, NY: de Gruyter.

Wirth, Louis. 1938. 'Urbanism as a way of life', American Journal of Sociology 44. 1-24. 
